\title{
ÅTERLÄMNING AV ISLÄNDSKA FÖREMÅL FRÅN DANMARK I93O
}

\author{
Anna Torbjörg Torgrimsdóttir
}

I juni månad 1930 firade islänningarna Alltingets 1000-årsjubileum. Före själva ceremonin träffade Danmarks statsminister, Thorvald Stauning, sin isländska kollega, Tryggvi Thórhallsson och överlämnade, som en jubileumsgåva, ca 150 museiföremål ur Danmarks Nationalmuseum, eller hälften av museets samling av isländska förhistoriska och medeltida föremål.

Huvuddelen av samlingen hade kommit till Oldsagsmuseet, Nationalmuseets föregångare, under 1800-talet, när Island fortfarande var en del av Danmark. Några föremål härstammade från Det Kongelige Kunstkammer, men andra föremål hade museet fått som gåvor eller med köp av privatpersoner. Dessutom förvärvade Den Kongelige Oldsagskommission som stod bakom Oldsagsmuseet direkt från Island en del föremål som "fortjene især at burde opbevares $i$ et Museum for Fædrenelandets Oldsager" som det då hette. ${ }^{1}$

Att hälften av den äldsta samlingen av isländska föremål återlämnades 1930 berodde inte på tillfälligheter, utan var ett resultat av långvariga förhandlingar mellan politiker och sakkunniga. En viktig politisk förutsättning för dessa förhandlingar var att Danmark 1920 tog över Norra Slesvig och samtidigt fick både arkivalier och museiföremål från Tyskland. Isländska politiker tyckte då att tiden var mogen för att återuppta gamla isländska krav från 1907 om återlämning av ämbetsarkiv ur danska institutioner. Alltinget röstade för en resolution år 1924 och då kraven bemöttes positivt från dansk sida beslöt isländska politiker att det skulle undersökas om några isländska föremål fanns i danska museer och i så fall kräva dem tillbaka. ${ }^{2}$

Tre månader senare, den 21 februari 1925, krävde Alltinget $\mathrm{i}$ en resolution till landets regering återförande av alla isländska museiföremål ur danska museer. ${ }^{3}$ Utgångspunkten för kraven var att alla de isländska föremål som danska museer förvarade utan att ha fătt eller köpt dem av föremålens lagliga ägare skulle tillbaka till Island och dessutom alla de föremål Oldsagskommissionen hade förvärvat från landet.

Samma sommar diskuterades kraven i Dansk-isländsk nämnd som tillkommit 1918, när Island fick självstyre från Danmark. Inom nämnden träffades varje sommar, representanter från Danmarks Rigsdag och Islands Allting och diskuterade de nya förhållanden som rådde mellan Island och Danmark och upprättade en rad avtal och överenskommelser. Både de isländska och de danska politi- 
18 kerna såg på de isländska kraven om arkivalier och museiföremål som en naturlig följd av de två ländernas åtskiljande. Förhandlingarna i nämnden ägde rum i ömsesidig förståelse. ${ }^{4}$

De danska representanterna efterlyste ett register över de föremål Island krävde återlämnade. Av en ren tillfällighet var Matthías Thórdarson direktör för Islands Nationalmuseum på resa i Köpenhamn. Han blev insatt i de isländska kraven och gjorde en lista på ca 120 föremål i Köpenhamnsmuseet. ${ }^{5}$ Matthías som efter detta fungerade som sakkunnig ändrade litet på kravens utgångspunkter. På listan återfanns därför de föremål som hade kommit till Köpenhamn med myndigheters inblandning och alla jordfunna föremål som hade skickats från Island till Oldsagsmuseet i Köpenhamn, men inte de föremål som museet hade köpt eller fătt av privatpersoner. ${ }^{6}$

Det visade sig att vara svårt att i praktiken bestämma hur och varför alla de isländska föremålen hade kommit till Danmark. Nationalmuseets kataloger var både kortfattade om förvärvssätt och ofta svårtolkade och det var därför omöjligt att alltid avgöra med vilken rätt föremålen hade kommit till museet. Därför bestämdes på Dansk-isländsk nämnds sommarmöte 1926, efter ett förslag från danskarna i nämnden, att ändra på förhandlingarnas grunder och att begära av de två regeringarna att lösa frågan på ett praktiskt sätt. "Ett praktiskt sätt" innebar att samlingens största del skulle till Island. Den del som blev kvar i Köpenhamn skulle inte bara ha ett speciellt värde för Nationalmuseet utan också att museet i Reykjavík redan hade liknande föremål i sin ägo. ${ }^{7}$

Både Islands och Danmarks regeringar verkar ha varit nöjda med denna praktiska lösning på återlämningskraven och att ha varit beredda att skriva ett avtal om saken. Det blev bestämt att direktörerna för båda museerna skulle träffas sommaren 1927 och gå igenom föremålen för att se vilka som skulle återlämnas.

Direktören för Danmarks Nationalmuseum, Dr. M. Mackeprang, hade från första början avvisat alla krav på återlämnande, utom av ett fåtal föremål han själv tyckte att Nationalmuseet kunde undvara. Men av Dansk-isländsk nämnds beslut var tydligt att politikerna skulle tvinga fram återlämnande. Det fick Mackeprang att ändra taktik och han började försöka påverka vilka föremål och hur många skulle återlämnas. Istället för att som tidigare, undvika utbildningsministeriets frågor och endast tala om den vetenskapliga vikt föremålen hade för Nationalmuseet, började Mackeprang aktivt delta i förhandlingar och motarbeta Dansk-isländsk nämnds förslag. Han informerade de danska politikerna om föremålens höga penningvärde och betonade risken av att ett återlämnande av föremål till Island sannolikt skulle betyda andra utlämningskrav, speciellt från Norge. ${ }^{8}$ Mackeprangs lobbying resulterade $\mathrm{i}$ att Danmarks Undervisningsminister J. Byskov beslöt att kommande förhandlingar mellan Mackeprang och Matthías Thórdarson skulle utgå från "frit sagligt Grundlag", men inte utifrån Danskisländsks nämnds praktiska sätt. Detta beslut meddelades endast Mackeprang och det danska statsministeriet. ${ }^{9}$

När de båda museidirektörerna träffades på försommaren 1927 trodde Matthías Thórdarson därför att de skulle förhandla efter Dansk-isländska nämndens beslut. Att han bara skulle peka ut den del av Nationalmuseets samling han skulle ta med hem till Island. Matthías lade därför fram en ny och utökad lista över de föremål han ville få återlämnade, 
totalt ca 233 nummer. Listan innehöll Nationalmuseets alla isländska föremål från förhistorisk tid, alla medeltida föremål och 34 av Nationalmuseets ganska omfattande samling av föremål från nyare tid. Den listan blev förhandlingarnas utgångspunkt. Det visade sig dock att Mackeprang hade invändningar och till slut enades de två herrarna om att ca 105 nummer skulle avstås till Island och att ca 52 nummer skulle stanna kvar i Köpenhamn. Var de resterande ca 76 föremålen skulle förvaras kunde de inte enas om.

Inte heller Dansk-isländsk nämnd som träffades senare samma sommar, kunde komma vidare i förhandlingarna. Då ställde plötsligt islänningarna i Dansk-isländsk nämnd minimikrav genom en lista på 25 föremål. Alla dessa 25 föremål var riktiga klenoder och alla fanns med bland de föremål museidirektörerna inte kunde enas om. Dessutom hade föremålen kommit till Köpenhamn på Oldsagskommissionen begäran eller utan den laglige ägarens tillåtelse. Minimikraven var med andra ord i enlighet med den ursprungliga Alltingsresolutionen från året 1925. Dessa föremål ville islänningarna ha och var, om det så behövdes, villiga att avstå från alla andra krav. Det och att Mackeprang snabbt tackade nej till det nya förslaget, visar väl vad trätan egentligen handlade om: de riktiga klenoderna som båda museerna ville komma åt fanns på den lista de inte kunde enas om.

Eftersom ingen lösning fanns på delningen begärde Dansk-isländsk nämnd att den danska regeringen skulle tillsätta en ny sakkunnig nämnd. Den skulle ha som uppdrag att lösa saken varvid större vikt skulle läggas på att möta de isländska önskemålen än tidigare gjorts. ${ }^{10}$

Den nya nämnden, kallad tremanskommissionen, bestod av tre danska museimän, di- rektören för Rosenborgsamlingerne greve Fr. Brockenhuus-Schack, professor emeritus Chr. Blinkenberg och museumsinspektör Otto Andrup. Deras förslag på uppdelningen av samlingen presenterades för de isländska representanterna på Dansk-isländsk nämnds möte sommaren $1929 .{ }^{11}$ Förslaget var, ur isländsk synpunkt, en väsentlig försämring jämfört med museidirektörernas förhandlingar två år tidigare. Det var tydligt att Dansk-isländsk nämnds förslag från sommaren 1926 hade förkastats. Nu var det Köpenhamnsmuseets behov som kom i första hand och de flesta klenoderna skulle stanna där. Island skulle bara få återlämnade två av de 76 föremål museidirektörerna inte kunde enas om och inget av de 25 föremål på minimikravlistan från 1927. Dessutom tog nämnden bort 19 föremål från museidirektörernas återlämningslista men lade till 11 föremål från listan över föremål som skulle ha stannat i Köpenhamn.

Den isländska delen av Dansk-isländsk nämnd kunde förstås inte godkänna förslaget och till slut begärde hela nämnden att de två regeringarna skulle avgöra saken $\mathrm{i}$ enlighet med nämndens "praktiska sätt". ${ }^{12}$

Tidigt våren 1930 ägde förhandlingar rum mellan den isländska regeringens representanter och den danska regeringen, men omfattningen på förhandlingen, vad som diskuterades och vilka, om några, beslut som togs vet jag inte ännu. ${ }^{13}$ Men den 21. maj 1930 mottog Dr. Mackeprang en lista från den danska regeringen över de föremål som skulle återlämnas till Island som en gåva på Alltingets 1000-årsdag.

Återlämningen baserades på museidirektörernas lista från sommaren 1927. Island fick alla de föremål Mackeprang hade godkänt för återlämnande, och 16 till, åtta kom från lis- 
20 tan över de föremål som skulle ha stannat $\mathrm{i}$ Köpenhamn och åtta av listan över de 76 nummer som museidirektörerna inte kunde enas om. Endast fyra föremål som återlämnades fanns med på den isländska minimikravlistan. Att återlämna föremålen som en gåva, löste två stora problem för danska politiker: För det första kunde givaren själv obehindrat välja vilka föremål som skulle återlämnas och dessutom kunde andra länder inte basera eventuella återlämningskrav av föremål på en gåva till Island. Men en gåva innebar också en nackdel: Det gick att ställa nya krav på återlämning!

Några dagar efter överlämningen höll Danskisländsk nämnd sitt sommarmöte på Island. Där tackade den isländske utbildningsministern, Jónas Jónasson, för gåvan och sade att lösningen på frågan var mycket tillfredsställande och att den isländska regeringen var "meget glade for dette Resultat, der var Vidnesbyrd om et Storsind, som var meget sjældent udenfor Skandinavien." 14 Från dansk sida tolkade man dessa ord som att Island inte skulle ställa några mer krav. Men de kunde inte ha haft mer fel. Nya krav ställdes. Först år 1938 och sedan några gånger till, tills de två länderna, 1965, skrev på avtalet om återlämning av de isländska handskrifterna. Då lovade man från Islands sida att aldrig mer ställa några krav på isländska handskrifter, arkivalier eller museiföremål i danska institutioner eller i privat ägo.

Att den isländska samlingen av förhistoriska och medeltida föremål i Danmarks Nationalmuseum delades itu året 1930 råder det ingen tvekan om. Inte heller att jubileumsgåvan innehöll några av Islands Nationalmuseums, idag, märkligaste föremål, bland annat det mäktigaste föremålet av alla, Valthjófsstadardörren. Men lika sant är det att de fles- ta stora klenoderna, några bland Islands finaste och värdefullaste kulturhistoriska föremål, blev kvar i Köpenhamn efter delningen 1930. Några få av föremålen är utställda i det danska museet men många, speciellt de mer vanliga, är magasinerade och svårtillgängliga för isländska forskare och allmänhet och har därmed helt eller delvis försvunnit ur isländsk kulturhistoria.

\section{Noter}

1. Kristján Eldjárn: Fadrenelandets Oldsager Stúdentabladid 1. des 1951. s. 18-20. Ur ett brev från Oldsagskommissionen till Stiftmyndigheterna på Island den 23 maj 1818: "Efter de os hidindtil fra Præsterne i Island indkomne befalede Efterretninger om de der befindtlige Oldsager, ere vi blevne opmærksomme paa fölgende vævede eller broderede Tapetserier, Alterklæder, m.m. Kirkerne tilhörende som tildels ere allerede blevne gandske ubrugbare som Kirkeprydelser, men som dog synes at være mærkværdige for Oldgrandskning og Kunsterne, samt fortjene især at burde opbevares i et Museum for Fædrenelandets Oldsager"

2. Thjódskjalasafn Íslands: Stjórnarrád Íslands. Db. 5 nr. 511 . Mötesprotokoll för den isländske delen av Dansk-isländsk nämnd 22. november 1924.; Altingistídindi A 1925 s. 189.

3. Altingistídindi A 1925. s. 246.

4. Dansk-islandsk nevn protokol over forhandlingerne $i$ aarene 1919-1939. Udgivet af nævnets danske afdeling (Kövenhamn 1944). Danmarks Nationalmuseum: Arkiv. Brev från Dansk-islandsk Nævn, danske Afdeling till Danmarks Statsminister den 23. juni 1926.

5. Matthías gjorde en lista på ca 80 föremål i augusti 1925 och en tilläggslista på ca 40 föremål i april 1926. Totalt ca 120 föremål.

6. Thjódskjalasafn Íslands: Sendirádid í Kaupman- 
nahöfn. Db. IV nr. 9. Skjalakrafa. Ett brev från Matthías Thórdarson till Islands Gesandt i Köpenhamn 22. februari 1930.

7. Dansk-islandsk navn protokol, s. 94-97.

8 Danmarks Nationalmuseum: Arkiv. T.ex. 30. maj 1924, Dr. Mackeprangs kallelse till Museumsraadsmöde den 4. december 1926 och ett brev från Dr. Mackeprang till J. Byskov undervisningsminister den 16. marts 1927.

9. Danmarks Nationalmuseum: Arkiv. Brev från Undervisningsministeriet till Dr. Mackeprang den 12. maj 1927, brev från Dr. Mackeprang till Undervisningsministeriet den 16. maj 1927 och brev från Undervisningsministeriet till Dr. Mackeprang den 18. maj 1927.
10. Dansk-islandsk navn protokoll, s. 114-115.

11. Dansk-islandsk navn protokoll, s. 140.; Danmarks Nationalmuseum: Arkiv. Kommissitionsindstillingen den 27 juni 1929.

12. Dansk-islandsk navn protokoll, s. 145 .

13. Se t.ex. Thjódskjalasafn Íslands: Sendirádid í Kaupmannahöfn. Db IV nr. 9. Skjalakrafa. Brev från Matthías Thórdarson till Islands Gesandt den 22. februari 1930.

14. Dansk-islandsk navn protokoll, s. 151-152.

Anna Torbjörg Torgrimsdóttir, mag.stud. i museivetenskap, Göteborgs universitet.

Adr. Brattåskärrsvägen 99, S-433 64 Sävedalen

E-mail: anna.torbjorg@telia.com 